\title{
The mineralized veins and the impact of old mine workings on the environment at Segura, central Portugal
}

\author{
I.M.H.R. Antunes ${ }^{a, *}$, A.M.R. Neiva ${ }^{\text {b }}$, M.M.V.G. Silva ${ }^{b}$ \\ ${ }^{a}$ Polytechnic Institute of Castelo Branco, 6000 Castelo Branco, Portugal \\ ${ }^{\mathrm{b}}$ Department of Earth Sciences, University of Coimbra, 3000 Coimbra, Portugal
}

\begin{abstract}
At Segura, granitic pegmatite veins with cassiterite and lepidolite, hydrothermal $\mathrm{Sn}-\mathrm{W}$ quartz veins and $\mathrm{Ba}-\mathrm{Pb}-\mathrm{Zn}$ quartz veins intruded the Cambrian schist-metagraywacke complex and Hercynian granites. Cassiterite from $\mathrm{Sn}-\mathrm{W}$ quartz veins is richer in $\mathrm{Ti}$ and poorer in $\mathrm{Nb}$ and $\mathrm{Nb}+\mathrm{Ta}$ than cassiterite from granitic pegmatite. Wolframite from $\mathrm{Sn}-\mathrm{W}$ quartz veins is enriched in ferberite component. The $\mathrm{Sn}-\mathrm{W}$ quartz veins contain pyrrhotite, arsenopyrite, sphalerite, chalcopyrite, stannite, matildite and schapbachite and the $\mathrm{Ba}-\mathrm{Pb}-\mathrm{Zn}$ quartz veins have cobaltite, pyrite, sphalerite, chalcopyrite, galena and barite, which were analyzed by electron microprobe. The presently abandoned mining area was exploited for $\mathrm{Sn}, \mathrm{W}, \mathrm{Ba}$ and $\mathrm{Pb}$ until 1953. Stream sediments and soils have higher concentrations of metals than parent granites and schists. Sn, W, B, As and $\mathrm{Cu}$ anomalies found in stream sediments and soils are associated with $\mathrm{Sn}-\mathrm{W}$ quartz veins, while $\mathrm{Ba}, \mathrm{Pb}$ and $\mathrm{Zn}$ anomalies in stream sediments and soils are related to $\mathrm{Ba}-\mathrm{Pb}-\mathrm{Zn}$ quartz veins. $\mathrm{Sn}, \mathrm{W}, \mathrm{B}, \mathrm{As}, \mathrm{Cu}, \mathrm{Ba}, \mathrm{Pb}$ and $\mathrm{Zn}$ anomalies in stream sediments and soils are also related to the respective old mining activities, which increased the mobility of trace metals from mineralized veins to soils, stream sediments and waters. Stream sediments and soils are sinks of trace elements, which depend on their contents in mineralized veins and weathering processes, but $\mathrm{Sn}, \mathrm{W}$ and B depend mainly on a mechanic process. Soils must not be used for agriculture and human residence due to their $\mathrm{Sn}, \mathrm{B}$, As and $\mathrm{Ba}$ contents. Waters associated with mineralized veins were analyzed by flame atomic absorption spectroscopy (FAAS) and ICP-AES have high As, Fe and Mn and should not be used for human consumption and agriculture activities. The highest As values in waters were all related to $\mathrm{Sn}-\mathrm{W}$ quartz veins and the highest $\mathrm{Fe}$ and $\mathrm{Mn}$ values were associated with the $\mathrm{Ba}-\mathrm{Pb}-\mathrm{Zn}$ quartz veins. No significant acid drainage was found associated with the old mine workings.
\end{abstract}

(c) 2002 Elsevier Science B.V. All rights reserved.

Keywords: $\mathrm{Sn}-\mathrm{W}$; $\mathrm{Ba}-\mathrm{Pb}-\mathrm{Zn}$; Mineralizations; Soils; Stream sediments; Waters

\section{Introduction}

Mining and mineral-processing activities can modify the environment in a variety of ways. These activities affect relatively small areas, but they can have a large local impact on the environment. Mining

\footnotetext{
* Corresponding author. Tel.: +351-272339975; fax: +351272339901.

E-mail address: imantunes@esa.ipcb.pt (I.M.H.R. Antunes).
}

activities extract and process valuable pit materials, which are crushed and milled. These materials have large surfaces and are very susceptible to both erosion and chemical weathering, causing a potential danger to the environment.

Sulphide mineralization is notorious for producing acid waters bearing high concentrations of heavy metals from mining, which is a great environmental concern (Rahn et al., 1996). A major source of acid mine drainage may result from the closure of a mine 
and if it is not controlled, it can cause a serious threat to the environment.

Large amounts of metals found in soils, stream sediments and waters are related to the occurrence of polymetallic mineralization in mining areas (Marszalek and Wasik, 2000). Large heavy-metal concentrations are the most important indicators of a possible environmental hazard emanating from abandoned mines (Rösner, 1998). However, the element concentrations in the environment depend on their dissolution from rocks and subsequent mobility in stream sediments and waters. The abandoned mining sites are frequently located close to populated rural areas. Consequently, surface water contamination by acid mine drainage has the potential to contaminate subsurface waters, wells and irrigation water supplies (Allen et al., 1996).

In the past, the mining industry frequently showed a lack of concern for the environment. In particular, the disposal of waste has led to unsightly spoil heaps being left to disfigure the landscape and to pollute surface streams and groundwater. Today, however, the greater awareness of the importance of the environment has led to tighter regulations being imposed by many countries to lessen the impact of mining (Bell, 1998).

At Segura, central Portugal, there are $\mathrm{Sn}-\mathrm{W}$ and $\mathrm{Ba}-\mathrm{Pb}-\mathrm{Zn}$ mineralized deposits, which were exploited in the past for $\mathrm{Sn}, \mathrm{W}, \mathrm{Ba}$ and $\mathrm{Pb}$. The extractions ceased in 1953 and there has not been any significant development work in the area. The tailings and rejected materials were deposited on the ground and are not covered by vegetation. They are exposed to the air and water that can change the environmental geochemistry of the area.

This paper evaluates the geochemical impact of $\mathrm{Sn}-\mathrm{W}$ and $\mathrm{Ba}-\mathrm{Pb}-\mathrm{Zn}$ mineralized deposits and of the respective abandoned old mine workings on stream sediments, soils and waters at Segura.

\section{Geological setting}

The studied area, Segura, is located at central Portugal near the Portuguese-Spanish border (Fig. 1). At Segura, Hercynian granitic rocks intruded the

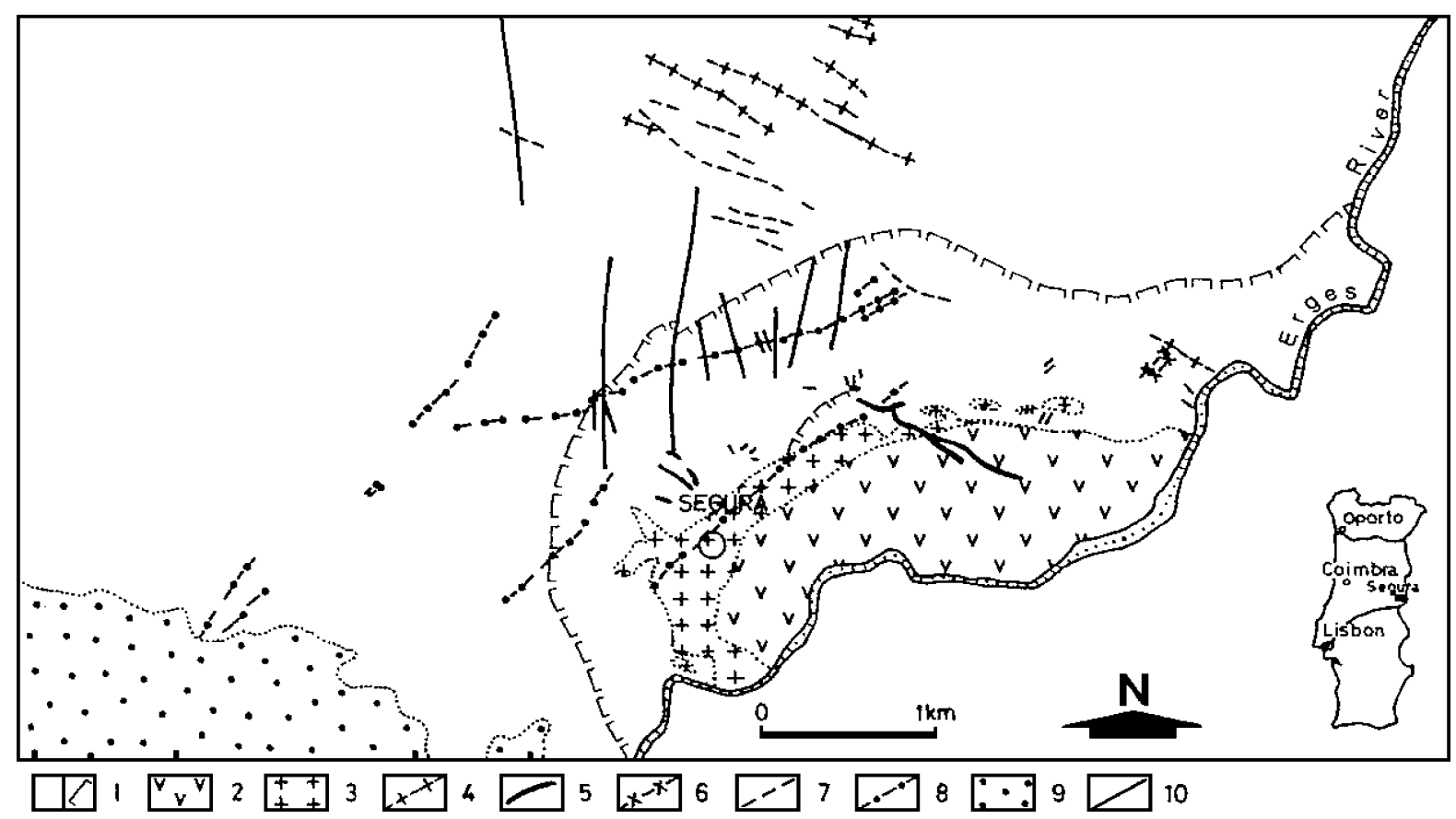

Fig. 1. Geological map of Segura, central Portugal. 1-Schist-metagraywacke complex, contact metamorphic aureole; 2 -medium-to coarsegrained two-mica granite; 3-medium-to fine-grained muscovite granite; 4-granodiorite porphyry veins; 5-granitic aplite veins; 6-Libearing granitic pegmatite veins with cassiterite; $7-\mathrm{Sn}-\mathrm{W}$ quartz veins; 8- $\mathrm{Ba}-\mathrm{Pb}-\mathrm{Zn}$ quartz veins; 9 -arkoses; 10 - faults. 
Cambrian schist-metagraywacke complex, which consists of alternating metapelites and metagraywackes with metaconglomerate and marble intercalations. The Segura pluton consists mainly of mediumto coarse-grained two-mica granite, but there is also a medium- to fine-grained muscovite granite. Both granites produced a contact metamorphic aureole up to $500 \mathrm{~m}$ thick (Fig. 1).

NW-SE to NNW-SSE granitic aplite veins intruded the schist-metagraywacke complex and granites, whereas subhorizontal NE-SW granitic pegmatite veins containing cassiterite and lepidolite and NW-SE to WNW-ESE quartz veins with cassiterite and wolframite intersect this complex. Later, ENEWSW to NNE-SSW quartz veins with barite, galena and sphalerite cut the schist-metagraywacke complex, while a few of them intruded the muscovite granite.

The mineralized veins fill late- to post-tectonic Hercynian faults. The granitic pegmatite veins with cassiterite and lepidolite are up to $15 \mathrm{~cm}$ thick and 300 $\mathrm{m}$ long. The lenticular quartz veins with cassiterite and wolframite are up to $10 \mathrm{~cm}$ thick and $1300 \mathrm{~m}$ long, but one of them has a thickness of $50 \mathrm{~cm}$. The lenticular quartz veins with barite, galena and sphaler- ite are up to $3 \mathrm{~m}$ thick, but at their contact with the muscovite granite, they appear many thin quartz veins of $2-15 \mathrm{~cm}$ thick. The longest one is $2500 \mathrm{~m}$. Commonly, barite represents $20-30 \%$ of the mineralogical composition of the veins (Instituto Geológico e Mineiro, 1988).

Nowadays, it is difficult to look for the mineralized veins. They are generally found through the old mine workings, which were carried out from 1942 to 1953. In this region, 100 tons of cassiterite, 12 tons of wolframite, 525 tons of barite and 211 tons of galena were exploited.

\section{Methods}

Detailed studies of samples collected from the mineralized veins and tailings included transmitted and reflected-light microscopy and electron microprobe analyses.

The ore minerals were analyzed for major and minor elements on a Cameca Camebax electron microprobe at Instituto Geológico e Mineiro, S. Mamede de Infesta, Portugal, and a Jeol JXA 8600

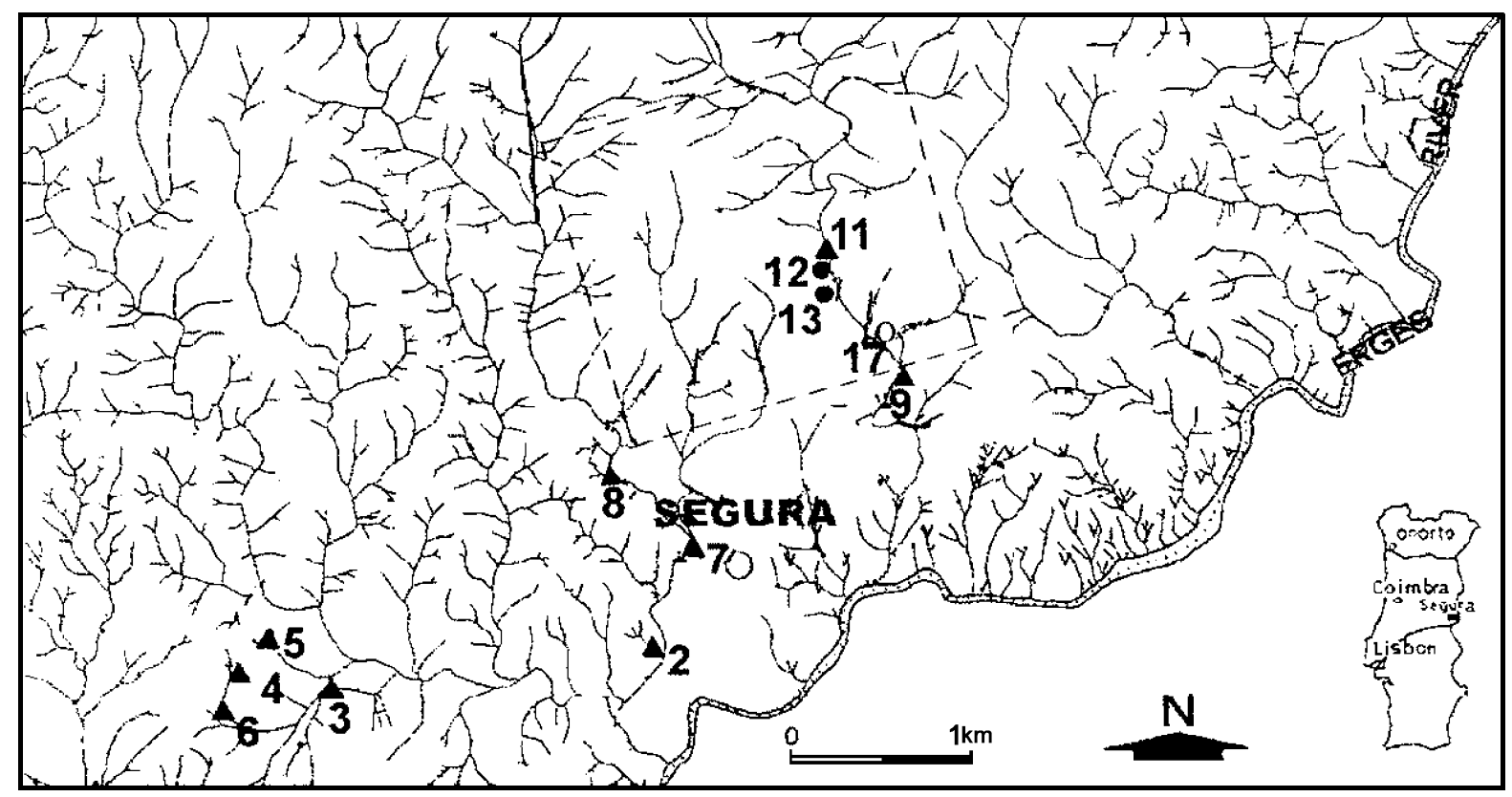

Fig. 2. Map of streams from Segura, central Portugal with the selected soil area and sample locations. $\square$ selected area for soil prospection (Instituto Geológico e Mineiro, 1988). Location of water points: - —springs; O—well; $\mathbf{\Delta}$-streams and small retentions. 
electron microprobe at Bristol University, UK. Standards used include cassiterite ( $\mathrm{Sn} \mathrm{L} \alpha), \mathrm{Ta}(\mathrm{L} \alpha), \mathrm{Nb}$ $(\mathrm{L} \alpha), \mathrm{W}(\mathrm{L} \alpha), \mathrm{MnTiO}_{3}(\mathrm{Mn} \mathrm{K} \alpha$ and $\mathrm{Ti} \mathrm{K} \alpha), \mathrm{Fe}_{2} \mathrm{O}_{3}$ $(\mathrm{Fe} \mathrm{K} \alpha)$, Mo $(\mathrm{L} \alpha)$ and apatite $(\mathrm{Ca} \mathrm{K} \alpha)$ for oxides, sphalerite $(\mathrm{Zn} \mathrm{K} \alpha$ and $\mathrm{S} \mathrm{K} \alpha)$, pyrite $(\mathrm{Fe} \mathrm{K} \alpha)$, galena $(\mathrm{Pb} \mathrm{M} \alpha), \mathrm{MnTiO}_{3}(\mathrm{Mn} \mathrm{K} \alpha), \mathrm{SnO}_{2}(\mathrm{Sn} \mathrm{L} \alpha), \mathrm{Ni}(\mathrm{K} \alpha)$, $\mathrm{Cu}(\mathrm{K} \alpha)$, As $(\mathrm{L} \alpha), \mathrm{Ag}(\mathrm{L} \alpha), \mathrm{Cd}(\mathrm{L} \alpha), \mathrm{Sb}(\mathrm{L} \alpha), \mathrm{Bi}$ $(\mathrm{M} \alpha)$ and $\mathrm{Mo}(\mathrm{L} \alpha)$ for sulphides and barite $(\mathrm{Ba} \mathrm{L} \alpha$ and $\mathrm{S} \mathrm{K} \alpha$ ), wollastonite $(\mathrm{Ca} \mathrm{K} \alpha)$, orthoclase $(\mathrm{Si} \mathrm{K} \alpha)$, galena $(\mathrm{Pb} \mathrm{M} \alpha), \mathrm{MgO}(\mathrm{Mg} \mathrm{K} \alpha)$ and $\mathrm{Fe}_{2} \mathrm{O}_{3}(\mathrm{Fe} \mathrm{K} \alpha)$ for sulphosalts.

In the Segura area (Fig. 2), a total of 717 samples of stream sediments were collected for mineral and geochemical prospections (Instituto Geológico e Mineiro, 1988). Of those, 671 samples of stream sediments were collected on schists and 46 samples on granites from selected locations between $50 \mathrm{~m}$ upstream and $100 \mathrm{~m}$ downstream the confluence of streams. Sn and $\mathrm{W}$ were determined by X-ray fluorescence, while $\mathrm{B}, \mathrm{As}, \mathrm{Cu}, \mathrm{Ba}, \mathrm{Pb}$ and $\mathrm{Zn}$ were analyzed by ICP-AES at Instituto Geológico e Mineiro, S. Mamede de Infesta with a precision of $10 \%$.
Based on the stream sediments data, an area of 3.8 $\mathrm{km}^{2}$ at north of Segura (Figs. 1 and 2) was chosen to improve geochemical prospecting and 1008 samples of soils derived from schist were collected up to a depth of $30 \mathrm{~cm}$. They were analyzed for $\mathrm{As}, \mathrm{B}, \mathrm{Cu}, \mathrm{Ba}, \mathrm{Pb}$ and $\mathrm{Zn}$ using the same analytical techniques applied for stream sediments and with the same precision of $10 \%$ (Instituto Geológico e Mineiro, 1988).

Tin, $\mathrm{W}, \mathrm{Cu}, \mathrm{Ba}, \mathrm{Pb}$ and $\mathrm{Zn}$ of parent chlorite phyllite and granites were analyzed by X-ray fluorescence, while As was determined by neutron activation. The measurements on phyllite samples were carried out at Manchester University (Neiva et al., 1990), while the granite samples were analyzed at Bristol University. The overall precision was 5\%.

The Segura region has a dry climate and during summer only, a few streams, springs and wells contain water. Twelve sampling points located close to the abandoned old mine workings (Fig. 2) were selected to collect water four times, at each sampling point, during a year and making a total of 48 water samples. Waters were collected at the end of summer (October 1996), at the middle of winter (December 1996), at the

Table 1

Electron-microprobe data on cassiterite, columbite and wolframite from Li-bearing granitic pegmatite veins and Sn-W quartz veins at Segura

\begin{tabular}{|c|c|c|c|c|c|c|c|}
\hline & \multicolumn{3}{|c|}{ Cassiterite } & \multirow[t]{3}{*}{ Manganocolumbite } & \multicolumn{3}{|c|}{ Wolframite } \\
\hline & \multicolumn{2}{|c|}{1} & \multirow[t]{2}{*}{2} & & & \multirow[t]{2}{*}{ Rim } & \multirow[t]{2}{*}{ Core } \\
\hline & a & $\mathrm{b}$ & & & & & \\
\hline & & & & & $\mathrm{FeO}$ & 16.94 & 15.79 \\
\hline $\mathrm{Nb}_{2} \mathrm{O}_{5}$ & 0.45 & 2.54 & 0.05 & 56.79 & $\mathrm{MnO}$ & 6.14 & 7.16 \\
\hline $\mathrm{Ta}_{2} \mathrm{O}_{5}$ & 0.59 & 1.46 & 0.37 & 23.12 & $\mathrm{CaO}$ & 0.01 & 0.02 \\
\hline $\mathrm{TiO}_{2}$ & - & 0.04 & 0.39 & 0.20 & $\mathrm{TiO}_{2}$ & 0.01 & 0.03 \\
\hline $\mathrm{SnO}_{2}$ & 98.76 & 95.17 & 99.15 & 0.23 & $\mathrm{Nb}_{2} \mathrm{O}_{5}$ & 0.03 & 0.04 \\
\hline $\mathrm{WO}_{3}$ & - & 0.34 & 0.03 & 4.87 & $\mathrm{WO}_{3}$ & 75.95 & 75.85 \\
\hline $\mathrm{MnO}$ & 0.11 & 0.28 & 0.03 & 13.68 & $\mathrm{MoO}_{3}$ & - & 0.03 \\
\hline $\mathrm{FeO}$ & - & 0.03 & 0.04 & 1.07 & $\mathrm{SnO}_{2}$ & 0.02 & 0.02 \\
\hline \multirow[t]{2}{*}{ Total } & 99.91 & 99.86 & 100.06 & 99.96 & Total & 99.10 & 98.94 \\
\hline & & & & & $\mathrm{Fe}$ & 0.722 & 0.674 \\
\hline $\mathrm{Nb}$ & 0.005 & 0.029 & - & 1.594 & Mn & 0.265 & 0.300 \\
\hline $\mathrm{Ta}$ & 0.004 & 0.010 & 0.003 & 0.390 & $\mathrm{Ca}$ & - & 0.001 \\
\hline $\mathrm{Ti}$ & - & 0.001 & 0.007 & 0.009 & $\mathrm{Ti}$ & 0.001 & 0.001 \\
\hline $\mathrm{Sn}$ & 0.987 & 0.945 & 0.988 & 0.006 & $\mathrm{Nb}$ & 0.001 & 0.001 \\
\hline W & - & 0.002 & - & 0.078 & W & 1.003 & 1.003 \\
\hline $\mathrm{Mn}$ & 0.002 & 0.006 & 0.001 & 0.719 & Mo & - & 0.001 \\
\hline $\mathrm{Fe}$ & - & 0.001 & 0.001 & 0.056 & $\mathrm{Sn}$ & 0.001 & - \\
\hline Total & 0.998 & 0.994 & 1.000 & 2.852 & Total & 1.993 & 1.981 \\
\hline
\end{tabular}

1-Li-bearing pegmatite vein, 2-Sn-W quartz veins; (a) lighter zone, (b) darker zone of the same crystal. Oxides in wt.\%. (-): Not detected. Cation formula based on 2, 6 and 4 atoms of oxygen for cassiterite, columbite and wolframite, respectively. Analyst: I. Antunes. 
middle of spring (March 1997) and at the beginning of the summer (July 1997).

Temperature, $\mathrm{pH}$, Eh, specific conductance and dissolved oxygen were determined in situ. The waters were acidified and kept at $4{ }^{\circ} \mathrm{C}$. $\mathrm{Na}, \mathrm{K}, \mathrm{Ca}, \mathrm{Mg}$, As, $\mathrm{Fe}, \mathrm{Mn}, \mathrm{Cu}, \mathrm{Pb}$ and $\mathrm{Zn}$ were determined by Spectrometer Perkin Elmer 303 flame atomic absorption at the Department of Earth Sciences, University of Coimbra, while Sn, B and Ba were determined by ICP-AES with a Spectrometer PU7000 ICP at Instituto Geológico e Mineiro, S. Mamede de Infesta. Alkalinity and $\mathrm{Cl}^{-}$were determined by titrations. Sulphate was analyzed by gravimetry, while $\mathrm{NO}_{3}^{-}$was determined by molecular absorption spectrometry, at the Department of Earth Sciences, University of Coimbra. The precision of all analyses was within $\pm 5 \%$. Sn, B, Cu and $\mathrm{Pb}$ were not detected in waters from Segura (Antunes, 1999).

\section{Results and discussion}

\subsection{Geochemistry of ore minerals}

Cassiterite from Li-bearing granitic pegmatites is zoned and the darker zones are richer in $\mathrm{Nb}$ and $\mathrm{Ta}$ than the lighter zones (Table 1), which are nearly pure $\mathrm{SnO}_{2}$. The darker zones are oscillatory and have $\mathrm{Nb}>\mathrm{Ta}$ and $\mathrm{Mn}>\mathrm{Fe}$. Manganocolumbite exsolutions (Table 1) were found particularly in darker zones of cassiterite. Cassiterite from $\mathrm{Sn}-\mathrm{W}$ quartz veins is unzoned, does not show any exsolutions and is poorer in $\mathrm{Nb}$ and $\mathrm{Nb}+\mathrm{Ta}$ and richer in $\mathrm{Ti}$ than cassiterite from Li-bearing granitic pegmatite veins (Table 1 and Fig. 3).

Wolframite occurs in the $\mathrm{Sn}-\mathrm{W}$ quartz veins and is richer in ferberite component than in heubnerite component (Table 1).

Sulphides and sulphosalts occur in quartz veins. Their average chemical compositions are given in Table 2. In $\mathrm{Sn}-\mathrm{W}$ quartz veins, the later sphalerite associated with wolframite is richer in $\mathrm{Zn}$ and poorer in $\mathrm{Fe}$ than the earlier sphalerite. Generally, sphalerite from $\mathrm{Ba}-\mathrm{Pb}-\mathrm{Zn}$ quartz veins is richer in $\mathrm{Zn}$ and poorer in $\mathrm{Fe}$ than sphalerites from $\mathrm{Sn}-\mathrm{W}$ quartz veins (Table 2). Chalcopyrite from $\mathrm{Ba}-\mathrm{Pb}-\mathrm{Zn}$ quartz veins is richer in $\mathrm{Cu}$ and $\mathrm{Fe}$ than chalcopyrite from $\mathrm{Sn}-\mathrm{W}$ quartz veins (Table 2).

In the $\mathrm{Sn}-\mathrm{W}$ quartz veins, matildite is richer in $\mathrm{Ag}$ and $\mathrm{Bi}$ and poorer in $\mathrm{Pb}$ than schapbachite (Table 2). Stannite with the composition $\mathrm{Cu}_{1.93}\left(\mathrm{Fe}_{0.79} \mathrm{Zn}_{0.21}\right)$ $\mathrm{SnS}_{4}$ also occurs in these veins and is the last sulphide.

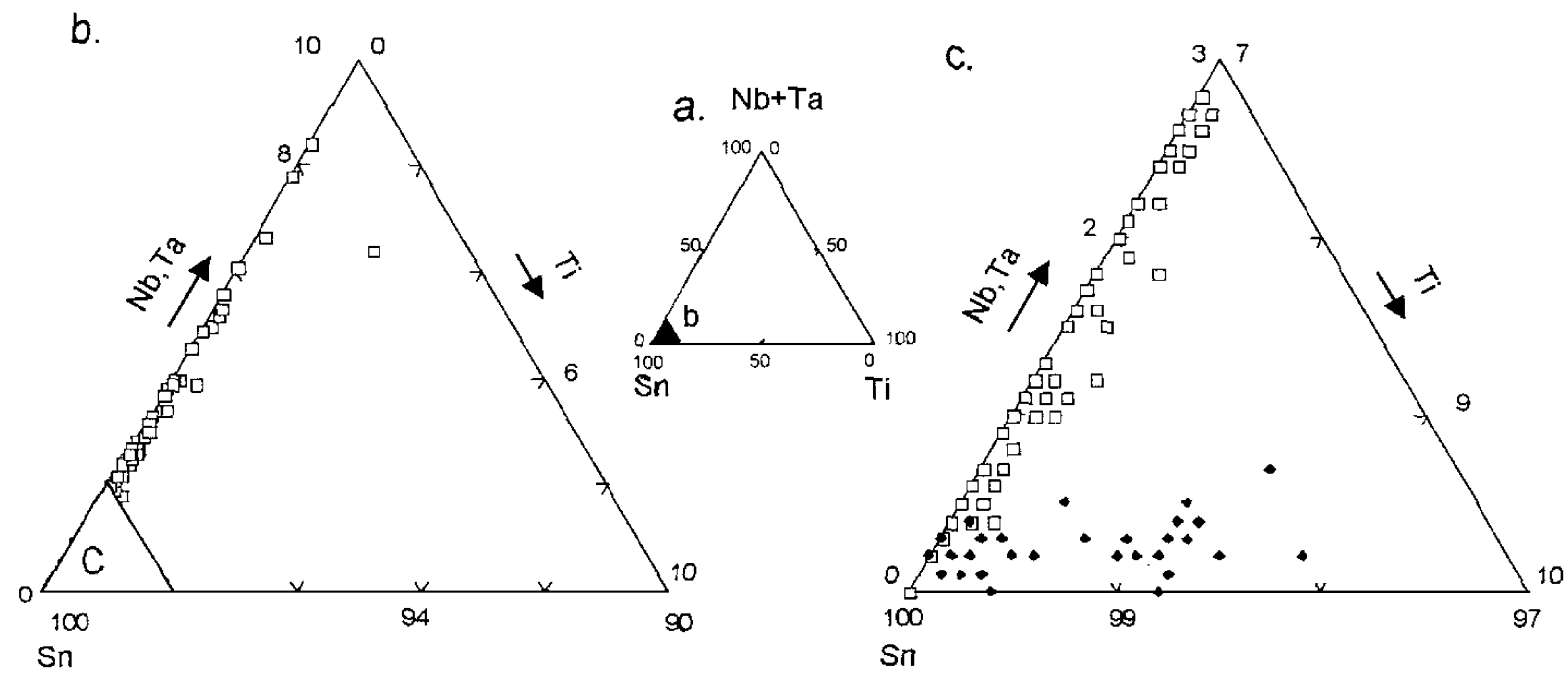

Fig. 3. (a) (Nb,Ta)-Ti-Sn diagram showing the location of diagram (b); (b) composition of the cassiterite richest in $\mathrm{Nb}+\mathrm{Ta}$ from Li-bearing granitic pegmatite veins from Segura and showing the location of cassiterite in diagram (c), which is expanded in the following figure to avoid data superposition; (c) cassiterites from Li-bearing granitic pegmatite veins and $\mathrm{Sn}-\mathrm{W}$ quartz veins from Segura. Symbols: $\square-$ granitic pegmatite; $\downarrow-\mathrm{Sn}-\mathrm{W}$ quartz veins. 
Table 2

Electron-microprobe analyses (wt.\%) of some sulphides and sulphosalts from $\mathrm{Sn}-\mathrm{W}$ quartz veins and $\mathrm{Ba}-\mathrm{Pb}-\mathrm{Zn}$ quartz veins from $\mathrm{Segura}$

\begin{tabular}{llllllllllllllllllll}
\hline & & $\mathrm{Cu}$ & $\mathrm{Ag}$ & $\mathrm{Zn}$ & $\mathrm{Fe}$ & $\mathrm{Mn}$ & $\mathrm{Cd}$ & $\mathrm{Sb}$ & $\mathrm{As}$ & $\mathrm{Bi}$ & $\mathrm{Pb}$ & $\mathrm{Sn}$ & $\mathrm{Ni}$ & $\mathrm{Co}$ & $\mathrm{Mo}$ & $\mathrm{Se}$ & $\mathrm{Te}$ & $\mathrm{S}$ & $\mathrm{Total}$ \\
\hline $\mathrm{a}$ & pyrrhotite & - & 0.03 & 0.51 & 56.31 & 0.02 & 0.02 & 0.04 & 0.02 & - & - & - & - & 0.03 & - & - & - & 42.69 & 99.67 \\
$\mathrm{a}$ & arsenopyrite & - & - & - & 35.26 & - & - & 0.01 & 44.71 & - & - & - & 0.02 & 0.03 & - & - & - & 19.52 & 99.55 \\
$\mathrm{a}$ & pyrite & - & - & - & 47.54 & - & - & - & 0.05 & - & - & - & 0.02 & 0.05 & - & - & - & 51.87 & 99.53 \\
$\mathrm{~b}$ & pyrite & - & - & - & 48.21 & - & - & - & 0.16 & - & - & - & 0.03 & 0.07 & - & - & - & 51.21 & 99.68 \\
$\mathrm{a}^{1}$ & sphalerite & 0.03 & - & 54.89 & 9.15 & 0.16 & 1.44 & - & - & - & - & - & - & 0.01 & - & - & - & 34.10 & 99.78 \\
$\mathrm{a}^{2}$ & sphalerite & 0.09 & - & 60.37 & 4.07 & 0.11 & 0.96 & - & - & - & - & - & - & 0.01 & - & - & - & 34.37 & 99.98 \\
$\mathrm{~b}$ & sphalerite & 0.11 & - & 61.79 & 2.56 & 0.02 & 0.75 & - & - & - & 0.16 & - & - & 0.01 & 0.09 & - & - & 34.53 & 100.02 \\
a & chalcopyrite & 34.10 & 0.27 & - & 29.24 & - & - & - & - & - & - & - & - & - & - & - & - & 36.03 & 99.64 \\
b & chalcopyrite & 34.62 & 0.08 & - & 29.51 & - & - & - & - & - & - & - & - & - & - & - & - & 35.41 & 99.62 \\
a & matildite & 0.40 & 27.81 & 0.34 & 0.12 & - & 0.13 & 0.04 & - & 52.87 & 1.22 & - & - & - & - & 0.36 & 0.14 & 16.49 & 99.92 \\
a & schapbachite & 0.73 & 18.12 & 0.35 & 0.40 & - & 0.11 & 0.06 & - & 34.22 & 30.49 & - & - & - & - & 0.26 & 0.03 & 15.42 & 100.19 \\
a & stannite & 28.59 & - & 3.18 & 10.30 & - & - & - & - & - & - & 27.59 & - & - & - & - & - & 29.91 & 99.57 \\
b & galena & 0.04 & 0.01 & 0.08 & 0.04 & 0.01 & 0.14 & 0.01 & - & 0.01 & 85.95 & - & - & - & - & - & - & 13.78 & 100.07 \\
\hline
\end{tabular}

(a) $\mathrm{Sn}-\mathrm{W}$ quartz veins, (b) $\mathrm{Ba}-\mathrm{Pb}-\mathrm{Zn}$ quartz veins; (-): not detected. Analyst: I. Antunes.

${ }^{1}$ Earlier sphalerites.

2 Later sphalerites.

Galena and barite were only found in the $\mathrm{Ba}-\mathrm{Pb}-$ $\mathrm{Zn}$ quartz veins. Commonly, both have homogeneous compositions (Tables 2 and 3), but barite has up to 1.82 wt.\% SrO.

Some secondary phases were also found, like scorodite (Table 3) as the alteration product of arsenopyrite in the $\mathrm{Sn}-\mathrm{W}$ quartz veins and anglesite, mimetite and kintoreite (Table 3 ) associated with the galena alter- ation. Mimetite with As/P ratio of 1.02-1.04 and kintoreite are presented in Neiva et al. (2001).

\subsection{Geochemistry of stream sediments and soils}

At Segura, stream sediments and soils are enriched in metal composition with respect to parent schist and granites, except for $\mathrm{Sn}$ in stream sediments on granites

Table 3

Electron microprobe analyses of barite and some secondary minerals of mineralized quartz veins from Segura

\begin{tabular}{|c|c|c|c|c|c|c|c|c|}
\hline & Barite & & Scorodite & & Anglesite & Mimetite & & Kintoreite \\
\hline $\mathrm{SiO}_{2}$ & 0.03 & $\mathrm{Fe}_{2} \mathrm{O}_{3}$ & 32.28 & $\mathrm{P}_{2} \mathrm{O} 5$ & 0.09 & 6.97 & & 19.52 \\
\hline $\mathrm{FeO}$ & 0.02 & $\mathrm{As}_{2} \mathrm{O}_{5}$ & 46.55 & $\mathrm{CaO}$ & - & 0.38 & & - \\
\hline $\mathrm{MgO}$ & - & Total & 78.83 & $\mathrm{As}_{2} \mathrm{O} 5$ & - & 11.51 & & - \\
\hline $\mathrm{CaO}$ & 0.04 & & & $\mathrm{SO}_{3}$ & 27.07 & - & & 1.62 \\
\hline $\mathrm{SrO}$ & 0.79 & & & $\mathrm{PbO}$ & 72.30 & 78.29 & & 31.00 \\
\hline $\mathrm{BaO}$ & 64.65 & & & $\mathrm{Fe}_{2} \mathrm{O}_{3}$ & - & - & & 32.39 \\
\hline $\mathrm{SO}_{3}$ & 34.58 & & & $\mathrm{CuO}$ & - & - & & 0.12 \\
\hline \multirow[t]{4}{*}{ Total } & 100.11 & & & $\mathrm{Cl}$ & - & 3.05 & & - \\
\hline & & & & & 99.46 & 100.20 & & 84.65 \\
\hline & & & & $\mathrm{O} \equiv \mathrm{Cl}$ & & 0.67 & & \\
\hline & & & & Total & & 99.53 & & \\
\hline $\mathrm{Ca}$ & 0.002 & $\mathrm{Fe}^{3+}$ & 1.000 & $\mathrm{~Pb}$ & 0.966 & 5.086 & $\mathrm{~Pb}$ & 1.027 \\
\hline $\mathrm{Sr}$ & 0.017 & As & 1.002 & $\mathrm{Ca}$ & - & 0.099 & $\mathrm{Cu}$ & 0.022 \\
\hline $\mathrm{Ba}$ & 0.975 & & & $\mathrm{P}$ & 0.004 & 1.424 & $\mathrm{Fe}^{3+}$ & 3.000 \\
\hline \multirow[t]{3}{*}{ S } & 1.002 & & & As & - & 1.453 & $\mathrm{P}$ & 2.034 \\
\hline & & & & $\mathrm{Cl}$ & - & 1.247 & S & 0.149 \\
\hline & & & & $\mathrm{S}$ & 1.008 & & & \\
\hline
\end{tabular}

Barite, anglesite, mimetite and kintoreite from $\mathrm{Ba}-\mathrm{Pb}-\mathrm{Zn}$ quartz veins; scorodite from $\mathrm{Sn}-\mathrm{W}$ quartz veins. Atomic contents calculated on the basis of $4(\mathrm{O})$ for barite and anglesite, $1 \mathrm{Fe}$ for scorodite, 13 anions for mimetite and $3 \mathrm{Fe}$ for kintoreite. Analyst: I. Antunes. 
Table 4

Trace element contents in ppm of parent rocks, stream sediments and soils from Segura compared with recommended maximum concentrations

\begin{tabular}{|c|c|c|c|c|c|c|c|c|c|c|c|c|}
\hline & \multicolumn{9}{|l|}{ Segura } & \multicolumn{3}{|c|}{ Soils } \\
\hline & \multicolumn{3}{|c|}{ Parent rocks } & \multicolumn{4}{|c|}{ Stream sediments on } & \multicolumn{2}{|c|}{ Soils on schists } & \multirow[t]{4}{*}{1} & \multirow[t]{4}{*}{2} & \multirow[t]{4}{*}{3} \\
\hline & \multirow{2}{*}{$\begin{array}{l}\text { Chlorite } \\
\text { phyllite }\end{array}$} & \multirow{2}{*}{$\begin{array}{l}\text { Two-mica } \\
\text { granite }\end{array}$} & \multirow{2}{*}{$\begin{array}{l}\text { Muscovite } \\
\text { granite }\end{array}$} & \multicolumn{2}{|l|}{ Schists } & \multicolumn{2}{|l|}{ Granites } & \multirow[t]{3}{*}{ Minimum } & \multirow[t]{3}{*}{ Maximum } & & & \\
\hline & & & & \multirow{2}{*}{ Minimum } & \multirow{2}{*}{ Maximum } & \multirow{2}{*}{ Minimum } & \multirow{2}{*}{ Maximum } & & & & & \\
\hline & Average & Average & Average & & & & & & & & & \\
\hline $\mathrm{Sn}$ & * & 20 & 49 & $<2.5$ & $>20$ & $<2$ & $>12.5$ & $<4$ & $>75$ & 5 & 50 & 300 \\
\hline W & $*$ & 6 & 13 & $<10$ & $>50$ & $<18$ & $>70$ & $<10$ & $>45$ & - & - & - \\
\hline B & - & - & - & $<46$ & $>175$ & $<40$ & $>60$ & $<55$ & $>300$ & 2 & - & - \\
\hline As & $*$ & 10 & 4 & $<20$ & $>175$ & $<20$ & $>45$ & $<20$ & $>375$ & 20 & 30 & 50 \\
\hline $\mathrm{Cu}$ & 28 & 2 & 1 & $<39$ & $>60$ & $<24$ & $>50$ & $<40$ & $>100$ & 150 & 100 & 500 \\
\hline $\mathrm{Ba}$ & 588 & 163 & 19 & $<625$ & $>1100$ & $<500$ & $>840$ & $<675$ & $>1500$ & 750 & 500 & 2000 \\
\hline $\mathrm{Pb}$ & 19 & 22 & 8 & $<27$ & $>75$ & $<40$ & $>75$ & $<20$ & $>120$ & 375 & 500 & 1000 \\
\hline $\mathrm{Zn}$ & 92 & 48 & 57 & $<125$ & $>225$ & $<125$ & $>165$ & $<125$ & $>290$ & 600 & 500 & 1500 \\
\hline
\end{tabular}

Contents of trace elements from Cambrian phyllite (Neiva et al., 1990). (*): Below limit of detection; (-): not determined or not defined. Recommended maximum values for: (1) agricultural soil; (2) human residence soil; (3) commerce and industry soil (Canadian Council of Ministers of the Environment, 1991). (-): Not defined.

(Table 4). In parent rocks, $\mathrm{Sn}, \mathrm{W}, \mathrm{Cu}$ and $\mathrm{Zn}$ are retained in micas and $\mathrm{Ba}$ and $\mathrm{Pb}$ are concentrated in $\mathrm{K}$-feldspar and micas. Arsenopyrite is the main concentrator of As, but is rare. The maximum concentrations for trace elements of soils are generally higher than those of stream sediments (Table 4).

In general, the highest content of $\mathrm{Sn}, \mathrm{W}, \mathrm{B}, \mathrm{As}, \mathrm{Cu}$, $\mathrm{Ba}, \mathrm{Pb}$ and $\mathrm{Zn}$ in stream sediments was found in those collected on schist (Table 4) and are from a restricted area at north of Segura (Fig. 2). The highest Sn, W and B concentrations on stream sediments are associated with exploited $\mathrm{Sn}-\mathrm{W}$ mineralizations. The highest concentrations on $\mathrm{As}$ and $\mathrm{Cu}$ are also associated with these mineralizations, but some of them, as well as the highest contents of $\mathrm{Ba}, \mathrm{Pb}$ and $\mathrm{Zn}$ are related to $\mathrm{Ba}-$ $\mathrm{Pb}-\mathrm{Zn}$ quartz veins, which were exploited in the past.

The class distribution of analyzed elements in soils is presented in Fig. 4. Sn, W, B, As and Cu anomalies of soils are mainly related to exploited $\mathrm{Sn}-\mathrm{W}$ quartz veins, which also contain arsenopyrite and chalcopyrite, while the anomalies on $\mathrm{Ba}, \mathrm{Pb}$ and $\mathrm{Zn}$ of soils are associated with quartz veins containing barite, galena and sphalerite (Figs. 1 and 2), which were also exploited. These mineralized veins mainly control the chemistry of stream sediments and soils.

The abandoned mine workings increase the mobility of trace elements from mineralized veins to soils and stream sediments because ore minerals have large exposed surfaces, which become weathered and, con- sequently, metals are released. Mechanical transport of metals, ore minerals and other materials also becomes important.

The mechanical process is the most responsible for $\mathrm{Sn}$ and $\mathrm{W}$ contents in stream sediments and soils. They are retained in micas derived from parent rocks and $\mathrm{Sn}-\mathrm{W}$ quartz veins, but are mainly concentrated in cassiterite and wolframite, respectively derived from these veins and their old mine workings (mine tailings and waste heaps). However, a small amount of Sn concentration is released by weathering of stannite, which is much less abundant than cassiterite in $\mathrm{Sn}-\mathrm{W}$ quartz veins. Tungstite can be formed by chemical alteration of wolframite. The mechanical process is also responsible for B content of stream sediments and soils and is retained in tourmaline derived from parent rocks, mineralized veins and waste heaps. However, B can be released by alteration of tourmaline into muscovite, which will take place mainly in soils.

Mechanical transport of sediment downstream is an important mechanism for the mobility of heavy metals from mineralized veins and tailings (Boulet and Larocque, 1998), particularly because at Segura, the separation of ore minerals from gangue minerals was carried out at the top of streams with the help of water. However downstream, the effect of chemical process increases progressively.

Arsenopyrite concentrates As, chalcopyrite retains $\mathrm{Cu}$ and $\mathrm{Zn}$, but sphalerite is the main concentrator of 

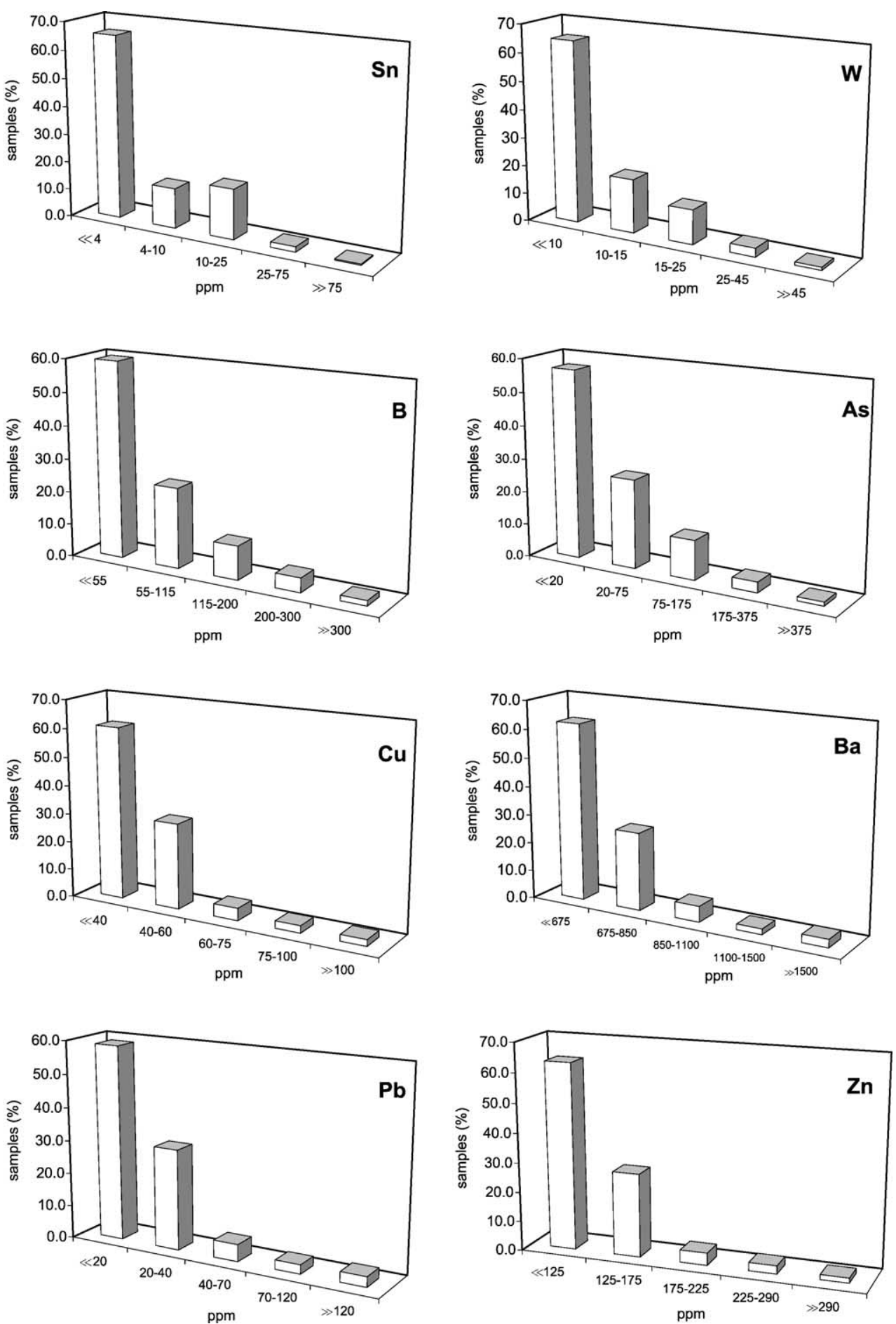

Fig. 4. The class distribution for trace element contents of soils from an area at north of Segura marked in Fig. 2. The lower limits of the classes are the average, $\sigma, 2 \sigma$ and $3 \sigma$. 
$\mathrm{Zn}$, while galena is responsible for $\mathrm{Pb}$ and barite concentrates $\mathrm{Ba}$ in the mineralized veins, mine tailings and in very small amount in waste heaps. The exploitation of these veins favored the exposition of sulphides and barite to weathering. Scorodite, anglesite, mimetite and kintoreite (Table 3) were found in the quartz veins and certainly also occur in mine tailings and waste heaps. Although some of the sulphide minerals and barite were carried by mechanical transport and occur in stream sediments, their alteration products are more important downstream.

The chemical processes involve selective dissolution of sulphides and barite from mineralized veins, mine tailings and waste heaps, transport of metals and their precipitations in soils and stream sediments. Small particles incorporated by mechanical process in soils will be weathered and metallic elements will be released. In soils, metals will be absorbed in clay minerals, Fe-oxides, Fe-hydroxides and organic matter. Soil $\mathrm{pH}$ and this absorption of metals controls metallic element contents (Boulet and Larocque, 1998) and explains the higher metal concentrations found in soils than in stream sediments (Table 4).

At Segura, metals in stream sediments and soils depend mainly on contents of these elements in mineralized veins and weathering processes, but mechanical process was the most important for $\mathrm{Sn}$,
$\mathrm{W}$ and B. Both stream sediments and soils are sinks of trace metals.

The soils have a large content in $\mathrm{Sn}, \mathrm{B}, \mathrm{As}$ and $\mathrm{Ba}$ and must not be used for agriculture and human residence because they are above the recommended maximum values-VMR (Table 4 and Fig. 5). The As levels are the most problematic due to the high toxicity of this element. Soils from Segura should not be used even for industrial settings (Fig. 5). It is significant that $28 \%$ of soil samples have As content higher than $50 \mathrm{ppm}$ (the recommended maximum value-VMR for industrial soil).

There are no recommended maximum values for W contents in soil. However, at Segura, W contents in soils are higher than those commonly found in soils (Brooks, 1972), confirming the mobility of W between $\mathrm{Sn}-\mathrm{W}$ quartz veins and soils.

\subsection{Geochemistry of waters}

The results of the chemical composition at water samples from Segura are given in Table 5. Most of the water samples contain arsenic above the detection limit and those were plotted in the Eh-pH diagram (Fig. 6). The waters associated with $\mathrm{Sn}-\mathrm{W}$ quartz veins fall in the $\mathrm{Fe}_{2} \mathrm{O}_{3}+\mathrm{H}_{2} \mathrm{AsO}_{4}{ }^{-}$stability field, while those associated with $\mathrm{Ba}-\mathrm{Pb}-\mathrm{Zn}$ quartz veins

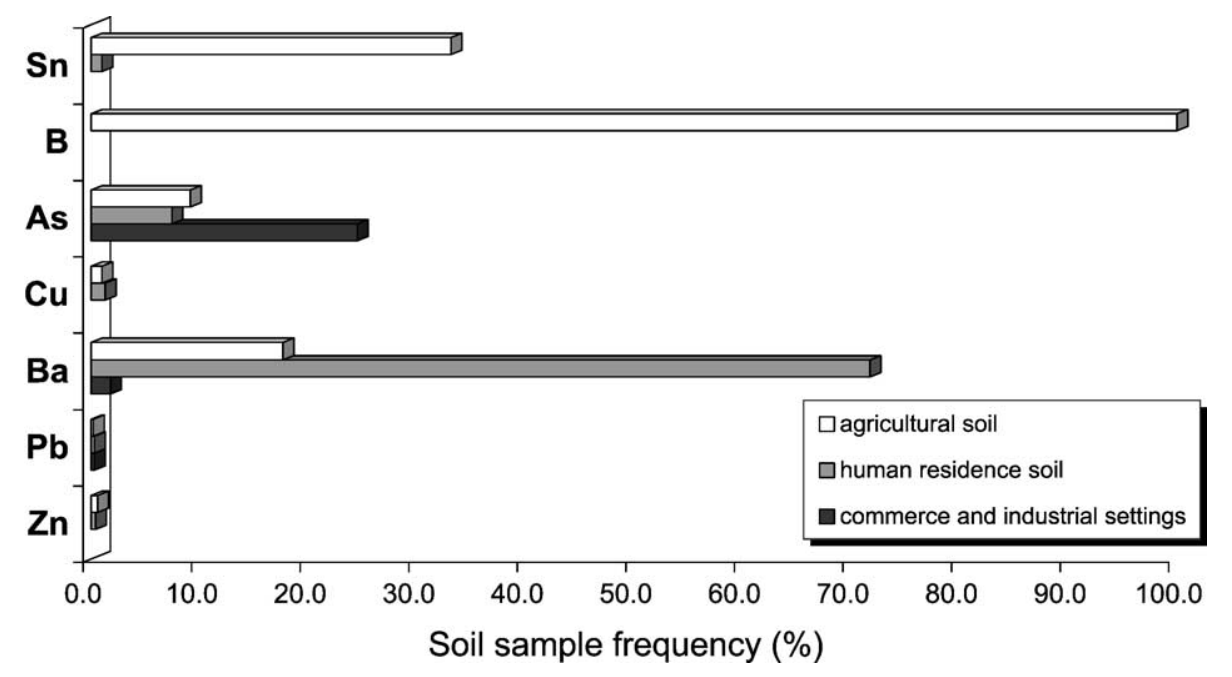

Fig. 5. Soil samples frequency (\%) from Segura above recommended maximum values (Canadian Council of Ministers of the Environment, 1991). 
Table 5

Concentration of constituents in waters from Segura

\begin{tabular}{|c|c|c|c|c|c|c|c|c|c|}
\hline $\begin{array}{l}\text { Quartz } \\
\text { veins }\end{array}$ & Sample & Dates & $\begin{array}{l}\text { Temp. } \\
\left({ }^{\circ} \mathrm{C}\right)\end{array}$ & $\mathrm{pH}$ & $\begin{array}{l}\text { Eh } \\
(\mathrm{mV})\end{array}$ & $\begin{array}{l}\text { Sp. Cond. } \\
(\mu \mathrm{S} / \mathrm{cm})\end{array}$ & $\begin{array}{l}\mathrm{Na} \\
(\mathrm{mg} / \mathrm{l})\end{array}$ & $\begin{array}{l}\mathrm{K} \\
(\mathrm{mg} / \mathrm{l})\end{array}$ & $\begin{array}{l}\mathrm{Ca} \\
(\mathrm{mg} / \mathrm{l})\end{array}$ \\
\hline \multirow[t]{20}{*}{$\mathrm{Sn}-\mathrm{W}$} & \multirow[t]{4}{*}{$12 \mathrm{~s}$} & July 97 & 20.7 & 6.95 & $*$ & 237 & 20.7 & 1.4 & 6.4 \\
\hline & & October 96 & 14.0 & 6.40 & 189 & 180 & 19.0 & 1.6 & 7.0 \\
\hline & & March 97 & 20.0 & 6.80 & 192 & 210 & 19.3 & 1.2 & 6.3 \\
\hline & & December 96 & 12.5 & 6.80 & 284 & 165 & 19.8 & 1.2 & 6.4 \\
\hline & \multirow[t]{4}{*}{$13 \mathrm{~s}$} & July 97 & 20.6 & 7.39 & $*$ & 318 & 24.4 & 2.8 & 10.8 \\
\hline & & October 96 & 13.0 & 6.80 & 284 & 230 & 25.4 & 2.1 & 9.7 \\
\hline & & March 97 & 19.0 & 7.20 & 181 & 245 & 23.8 & 1.2 & 8.4 \\
\hline & & December 96 & 11.0 & 7.00 & 281 & 195 & 21.3 & 1.3 & 8.1 \\
\hline & \multirow[t]{4}{*}{$17 \mathrm{w}$} & July 97 & 26.2 & 7.13 & $*$ & 177 & 14.8 & 1.1 & 5.0 \\
\hline & & October 96 & 12.0 & 6.60 & 340 & 130 & 13.9 & 1.0 & 6.4 \\
\hline & & March 97 & 19.5 & 6.70 & 189 & 118 & 12.1 & 0.9 & 3.3 \\
\hline & & December 96 & 12.0 & 6.70 & 294 & 80 & 9.9 & 0.6 & 3.1 \\
\hline & \multirow[t]{4}{*}{$9 \mathrm{st}$} & July 97 & 32.2 & 7.14 & $*$ & 194 & 15.0 & 2.7 & 7.1 \\
\hline & & October 96 & 14.2 & 7.50 & $*$ & 162 & 15.1 & 3.4 & 9.1 \\
\hline & & March 97 & 19.0 & 7.10 & 165 & 132 & 13.0 & 0.3 & 5.1 \\
\hline & & December 96 & 10.0 & 6.72 & 263 & 72 & 9.8 & 0.9 & 3.0 \\
\hline & \multirow[t]{4}{*}{$11 \mathrm{st}$} & July 97 & 28.3 & 7.07 & $*$ & 244 & 21.4 & 1.6 & 7.0 \\
\hline & & October 96 & 13.0 & 6.50 & 355 & 58 & 7.4 & 0.6 & 2.3 \\
\hline & & March 97 & 24.0 & 7.30 & 171 & 130 & 12.9 & 0.3 & 4.0 \\
\hline & & December 96 & 12.0 & 6.80 & 259 & 75 & 10.4 & 0.9 & 3.2 \\
\hline \multirow[t]{30}{*}{$\mathrm{Ba}-\mathrm{Pb}-\mathrm{Zn}$} & \multirow[t]{4}{*}{$2 \mathrm{st}$} & July 97 & 29.2 & 7.12 & $*$ & 764 & 57.1 & 16.4 & 34.4 \\
\hline & & October 96 & 16.7 & 7.50 & $*$ & 620 & 75.3 & 20.1 & 39.7 \\
\hline & & March 97 & 12.8 & 7.50 & 173 & 294 & 30.3 & 8.7 & 18.9 \\
\hline & & December 96 & 11.5 & 7.40 & 281 & 800 & 77.2 & 35.0 & 90.4 \\
\hline & \multirow[t]{4}{*}{$3 \mathrm{st}$} & July 97 & 30.7 & 8.00 & $*$ & 196 & 18.2 & 9.6 & 5.4 \\
\hline & & October 96 & 18.4 & 7.55 & $*$ & 175 & 13.9 & 8.1 & 15.5 \\
\hline & & March 97 & 18.0 & 7.20 & 177 & 70 & 6.9 & 0.8 & 4.4 \\
\hline & & December 96 & 6.0 & 6.60 & 271 & 22 & 6.8 & 0.9 & 1.8 \\
\hline & \multirow[t]{4}{*}{4 st } & July 97 & 22.5 & 7.55 & $*$ & 47 & 5.7 & 1.3 & 0.5 \\
\hline & & October 96 & 16.7 & 5.95 & $*$ & 51 & 6.5 & 1.8 & 0.9 \\
\hline & & March 97 & 17.0 & 5.60 & 210 & 35 & 5.1 & 1.4 & 0.5 \\
\hline & & December 96 & 10.5 & 5.20 & 296 & 30 & 5.1 & 3.5 & 0.6 \\
\hline & \multirow[t]{4}{*}{$5 \mathrm{st}$} & July 97 & 28.6 & 7.88 & $*$ & 111 & 5.5 & 2.3 & 5.0 \\
\hline & & October 96 & 16.5 & 8.25 & $*$ & 181 & 8.3 & 6.4 & 12.5 \\
\hline & & March 97 & 20.0 & 7.20 & 178 & 61 & 3.6 & 1.3 & 3.7 \\
\hline & & December 96 & 11.0 & 6.80 & 283 & 32 & 3.8 & 1.6 & 2.4 \\
\hline & \multirow[t]{4}{*}{$6 s t$} & July 97 & $*$ & $*$ & $*$ & $*$ & 13.8 & 22.3 & 10.8 \\
\hline & & October 96 & 16.1 & 5.90 & $*$ & 279 & 22.0 & 25.3 & 7.8 \\
\hline & & March 97 & 20.0 & 6.80 & 180 & 55 & 3.8 & 2.7 & 3.4 \\
\hline & & December 96 & 10.0 & 6.50 & 308 & 40 & 3.1 & 1.7 & 1.9 \\
\hline & \multirow[t]{4}{*}{$7 \mathrm{st}$} & July 97 & 26.6 & 6.85 & $*$ & 345 & 28.6 & 1.8 & 11.1 \\
\hline & & October 96 & 14.6 & 7.35 & $*$ & 280 & 29.0 & 1.7 & 7.8 \\
\hline & & March 97 & 20.0 & 7.40 & 168 & 165 & 16.5 & 0.4 & 6.6 \\
\hline & & December 96 & 7.5 & 7.10 & 284 & 180 & 19.2 & 1.8 & 12.5 \\
\hline & \multirow[t]{4}{*}{$8 \mathrm{st}$} & July 97 & 25.6 & 7.08 & $*$ & 328 & 24.2 & 3.8 & 1.3 \\
\hline & & October 96 & 15.8 & 7.40 & $*$ & 236 & 23.6 & 2.9 & 11.0 \\
\hline & & March 97 & 24.0 & 7.80 & 128 & 121 & 12.5 & 0.3 & 3.5 \\
\hline & & December 96 & 9.0 & 6.90 & 286 & 62 & 9.5 & 0.5 & 2.4 \\
\hline & VMAh & & 25.0 & 9.5 & & 400 & 150 & 12 & 100 \\
\hline & VMRr & & $* *$ & $* *$ & & $* *$ & $* *$ & $* *$ & $* *$ \\
\hline
\end{tabular}




\begin{tabular}{|c|c|c|c|c|c|c|c|c|c|}
\hline $\begin{array}{l}\mathrm{Mg} \\
(\mathrm{mg} / \mathrm{l})\end{array}$ & $\begin{array}{l}\text { As } \\
(\mathrm{mg} / \mathrm{l})\end{array}$ & $\begin{array}{l}\mathrm{Fe} \\
(\mathrm{mg} / \mathrm{l})\end{array}$ & $\begin{array}{l}\mathrm{Mn} \\
(\mathrm{mg} / \mathrm{l})\end{array}$ & $\begin{array}{l}\mathrm{Ba} \\
(\mathrm{mg} / \mathrm{l})\end{array}$ & $\begin{array}{l}\mathrm{HCO}_{3}^{-} \\
(\mathrm{mg} / \mathrm{l})\end{array}$ & $\begin{array}{l}\mathrm{Cl}^{-} \\
(\mathrm{mg} / \mathrm{l})\end{array}$ & $\begin{array}{l}\mathrm{SO}_{4}^{2-} \\
(\mathrm{mg} / \mathrm{l})\end{array}$ & $\begin{array}{l}\mathrm{NO}_{3}^{-} \\
(\mathrm{mg} / \mathrm{l})\end{array}$ & $\begin{array}{l}\text { Dry residue } \\
(\mathrm{mg} / \mathrm{l})\end{array}$ \\
\hline 11.6 & 0.081 & 3.69 & 0.57 & $*$ & 73.1 & 11.4 & 34.9 & 0.48 & 181.0 \\
\hline 12.1 & 0.409 & 5.76 & 0.52 & 0.12 & 77.6 & 12.6 & 34.5 & 0.30 & 190.9 \\
\hline 12.1 & 0.130 & 5.35 & 0.62 & $*$ & 73.2 & 10.0 & 39.7 & 0.21 & 175.2 \\
\hline 11.9 & 0.490 & 5.60 & 0.68 & $*$ & 74.8 & 12.7 & 39.8 & 0.11 & 167.1 \\
\hline 17.5 & 1.111 & 0.62 & 0.33 & $*$ & 115.8 & 17.1 & 40.8 & 0.77 & 218.3 \\
\hline 17.8 & 0.636 & 4.80 & 0.45 & 0.09 & 101.6 & 13.5 & 57.4 & 1.30 & 236.1 \\
\hline 15.0 & 0.326 & 4.38 & 0.15 & $*$ & 90.0 & 10.5 & 50.2 & 0.33 & 208.7 \\
\hline 14.2 & 1.190 & 5.94 & 0.63 & $*$ & 88.8 & 11.7 & 43.2 & 0.10 & 192.4 \\
\hline 7.5 & 0.122 & 4.20 & 0.22 & $*$ & 58.3 & 17.1 & 10.9 & 0.95 & 117.4 \\
\hline 8.8 & 0.082 & 2.10 & 0.37 & - & 41.6 & 14.5 & 34.9 & 6.00 & 132.7 \\
\hline 5.3 & 0.007 & 0.44 & 0.18 & $*$ & 30.8 & 10.4 & 17.8 & 0.36 & 89.1 \\
\hline 4.7 & 0.015 & 0.12 & 0.02 & $*$ & 22.4 & 10.5 & 14.3 & 4.95 & 100.4 \\
\hline 8.8 & 0.011 & 0.54 & 0.12 & $*$ & 58.3 & 17.1 & 20.9 & 0.61 & 125.9 \\
\hline 10.0 & 0.039 & 0.43 & 0.06 & 0.11 & 52.4 & 19.7 & 25.9 & 3.10 & 155.7 \\
\hline 7.0 & 0.002 & 0.13 & - & $*$ & 40.4 & 8.3 & 24.8 & 0.68 & 90.2 \\
\hline 3.8 & 0.001 & 0.21 & - & $*$ & 19.2 & 8.7 & 16.2 & 4.32 & 89.8 \\
\hline 4.1 & 0.047 & 3.41 & 0.41 & $*$ & 50.3 & 28.5 & 18.4 & 0.67 & 173.8 \\
\hline 3.2 & 0.002 & 0.43 & - & - & 15.2 & 9.1 & 10.5 & 4.00 & 69.0 \\
\hline 5.4 & 0.003 & - & - & $*$ & 32.0 & 7.8 & 22.6 & 0.11 & 80.1 \\
\hline 4.2 & 0.001 & 0.33 & 0.05 & $*$ & 26.4 & 9.2 & 16.3 & 2.12 & 77.1 \\
\hline 29.4 & 0.040 & 1.84 & 1.03 & $*$ & 155.7 & 102.4 & 54.7 & 0.70 & 460.7 \\
\hline 34.0 & 0.006 & 0.21 & 0.06 & 0.10 & 87.2 & 163.0 & 116.9 & 7.00 & 560.2 \\
\hline 15.0 & 0.003 & - & 0.03 & $*$ & 78.0 & 57.7 & 43.6 & 47.65 & 253.5 \\
\hline 28.9 & 0.056 & - & - & $*$ & 171.2 & 160.1 & 85.4 & 173.00 & 772.5 \\
\hline 7.8 & 0.045 & 2.12 & 0.27 & $*$ & 79.9 & 18.6 & 4.1 & 0.61 & 157.3 \\
\hline 8.8 & 0.012 & 1.26 & 0.50 & 0.22 & 107.2 & 16.0 & 9.9 & 1.30 & 149.7 \\
\hline 3.1 & 0.002 & 0.35 & 0.05 & $*$ & 38.2 & 3.0 & 9.0 & 0.19 & 83.9 \\
\hline 1.2 & - & 0.17 & - & $*$ & 14.0 & 3.9 & 9.0 & 0.38 & 62.2 \\
\hline 0.7 & - & 0.14 & 0.17 & $*$ & 5.6 & 5.3 & 5.7 & 0.26 & 38.5 \\
\hline 1.3 & 0.004 & 1.22 & 1.27 & 0.41 & 7.2 & 9.9 & 11.0 & 1.10 & 59.0 \\
\hline 0.8 & - & 0.26 & 0.05 & $*$ & 4.8 & 3.2 & 8.6 & 0.79 & 83.9 \\
\hline 1.1 & 0.002 & 0.37 & 0.16 & $*$ & 2.6 & 3.9 & 9.2 & 5.23 & 163.0 \\
\hline 6.5 & 0.005 & 0.33 & 0.20 & $*$ & 58.3 & 5.7 & 2.4 & 0.18 & 83.9 \\
\hline 13.8 & 0.005 & 0.38 & 0.37 & 1.60 & 130.8 & 8.7 & 5.9 & 0.60 & 141.3 \\
\hline 3.5 & - & 0.31 & - & $*$ & 36.0 & 2.0 & 4.0 & 0.32 & 58.4 \\
\hline 2.5 & 0.001 & 0.37 & 0.07 & $*$ & 24.4 & 2.4 & 4.4 & 0.73 & 68.2 \\
\hline 6.4 & 0.009 & 9.92 & 1.09 & $*$ & 97.4 & 27.3 & 6.2 & 2.56 & 142.9 \\
\hline 4.2 & 0.001 & 1.24 & 0.77 & 0.20 & 6.0 & 43.9 & 57.9 & 6.40 & 225.8 \\
\hline 2.1 & - & 1.70 & 0.10 & $*$ & 30.0 & 2.7 & 5.3 & 0.68 & 59.7 \\
\hline 1.1 & - & 0.53 & 0.07 & $*$ & 16.4 & 3.4 & 0.8 & 0.49 & 67.7 \\
\hline 17.6 & 0.051 & 2.77 & 1.35 & $*$ & 97.8 & 31.3 & 34.8 & 0.20 & 211.3 \\
\hline 18.7 & 0.008 & 0.32 & 0.18 & 0.07 & 44.0 & 35.6 & 87.1 & 0.10 & 241.7 \\
\hline 8.8 & 0.006 & 0.09 & - & $*$ & 45.2 & 10.6 & 35.4 & 0.33 & 128.8 \\
\hline 12.6 & 0.012 & 0.08 & - & $*$ & 48.0 & 21.9 & 34.1 & 23.48 & 198.0 \\
\hline 17.1 & 0.050 & 2.97 & 0.19 & $*$ & 94.2 & 14.2 & 60.1 & 0.50 & 283.1 \\
\hline 16.6 & 0.017 & 0.67 & - & 0.09 & 70.8 & 20.4 & 69.1 & 0.60 & 216.7 \\
\hline 4.8 & 0.002 & 0.04 & - & $*$ & 33.2 & 4.4 & 23.1 & 0.13 & 90.1 \\
\hline 3.5 & 0.001 & 0.33 & - & $*$ & 21.2 & 8.4 & 11.8 & 5.62 & 79.5 \\
\hline 50 & 0.050 & 0.20 & 0.05 & 0.001 & $* *$ & 25.0 & 250.0 & $* *$ & 1500.0 \\
\hline$* *$ & 0.100 & 5.00 & 0.20 & $* *$ & $* *$ & 70 & 575.0 & 50.00 & $* *$ \\
\hline
\end{tabular}




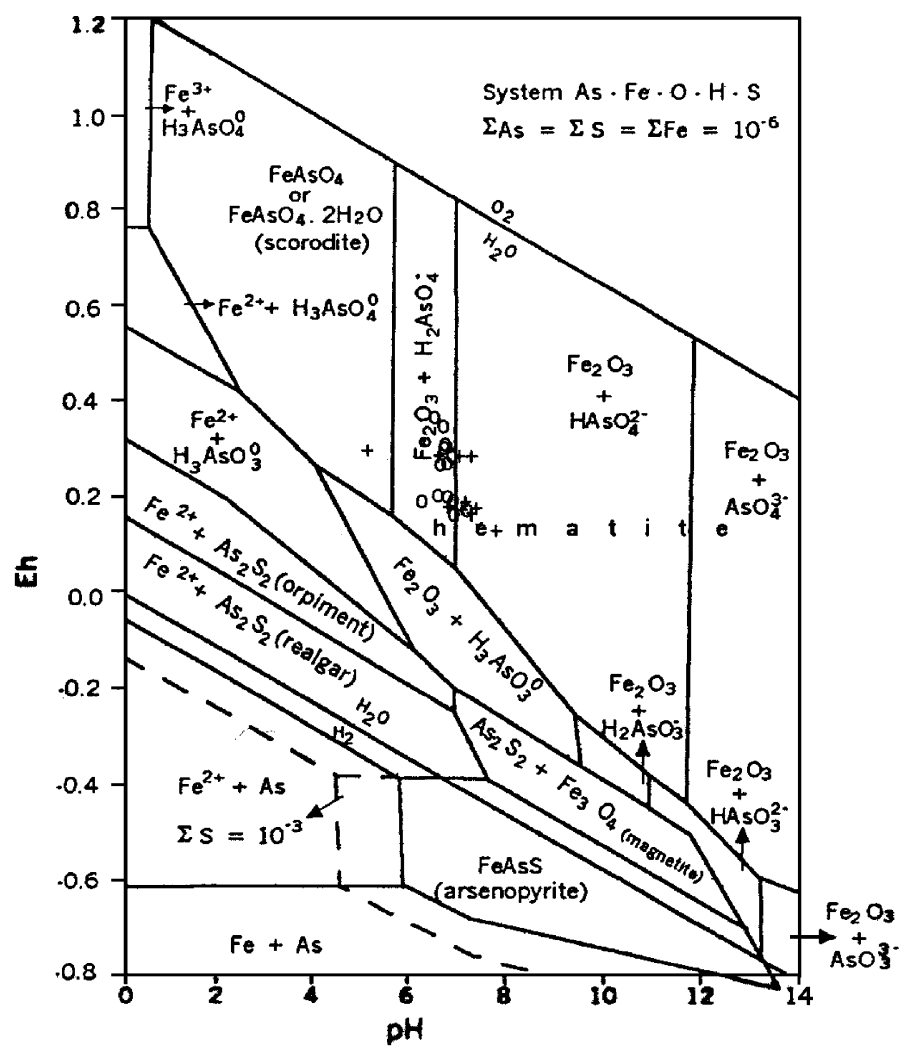

Fig. 6. Plot of water samples from Segura on the $\mathrm{Eh}-\mathrm{pH}$ diagram for the system As-Fe-O-H-S (Vink, 1996). Symbols: water samples associated with $\mathrm{O}-\mathrm{Sn}-\mathrm{W}$ quartz veins, $+-\mathrm{Ba}-\mathrm{Pb}-\mathrm{Zn}$ quartz veins.

plot mainly in the $\mathrm{Fe}_{2} \mathrm{O}_{3}+\mathrm{HAsO}_{4}{ }^{2-}$ field because commonly they have the highest $\mathrm{pH}$ values. Therefore, arsenopyrite and scorodite are not stable at Eh and $\mathrm{pH}$ values of the water samples from Segura. Arsenopyrite of $\mathrm{Sn}-\mathrm{W}$ quartz veins was oxidized and scorodite precipitated as found (Table 3). There was dissolution of some arsenopyrite and scorodite from these veins and arsenopyrite and mimelite from $\mathrm{Ba}-$ $\mathrm{Pb}-\mathrm{Zn}$ quartz veins, mine tailings and waste heaps. The waters associated with the $\mathrm{Sn}-\mathrm{W}$ quartz veins and As anomalies in soils have higher As contents than the waters associated with the $\mathrm{Ba}-\mathrm{Pb}-\mathrm{Zn}$ quartz veins. Generally, arsenic content decreases in waters from springs to wells and to streams associated with
$\mathrm{Sn}-\mathrm{W}$ quartz veins with increase in oxidizing Eh values (Table 5) because As is easily adsorbed by $\mathrm{Fe}$ oxyhydroxides at relatively high Eh values (Nickson et al., 2000).

The waters with the highest As concentrations also have high $\mathrm{Fe}$ and Mn contents (Table 5), but correlations are poor because the largest $\mathrm{Fe}$ and $\mathrm{Mn}$ concentrations were found in waters associated with $\mathrm{Ba}-\mathrm{Pb}-$ $\mathrm{Zn}$ quartz veins, while the highest As concentration was found in waters associated with $\mathrm{Sn}-\mathrm{W}$ quartz veins. The poor correlation between As and $\mathrm{Fe}$ was also found by Nickson et al. (2000). The highest Fe content may also have been derived by dissolution of pyrite, which is more abundant than arsenopyrite in

Notes to Table 5:

Data are presented from dry season to raining winter. s—Springs; w-well; st—stream and small retentions; Temp.- temperature; Spc. cond.specific conductance. $(-)$ : Not detected. $(*)$ : Not determined. VMAh-Human recommended values; VMRr-agricultural recommended values (Portuguese law, 1998). (**): Not defined.

Analyst: I. Antunes. 


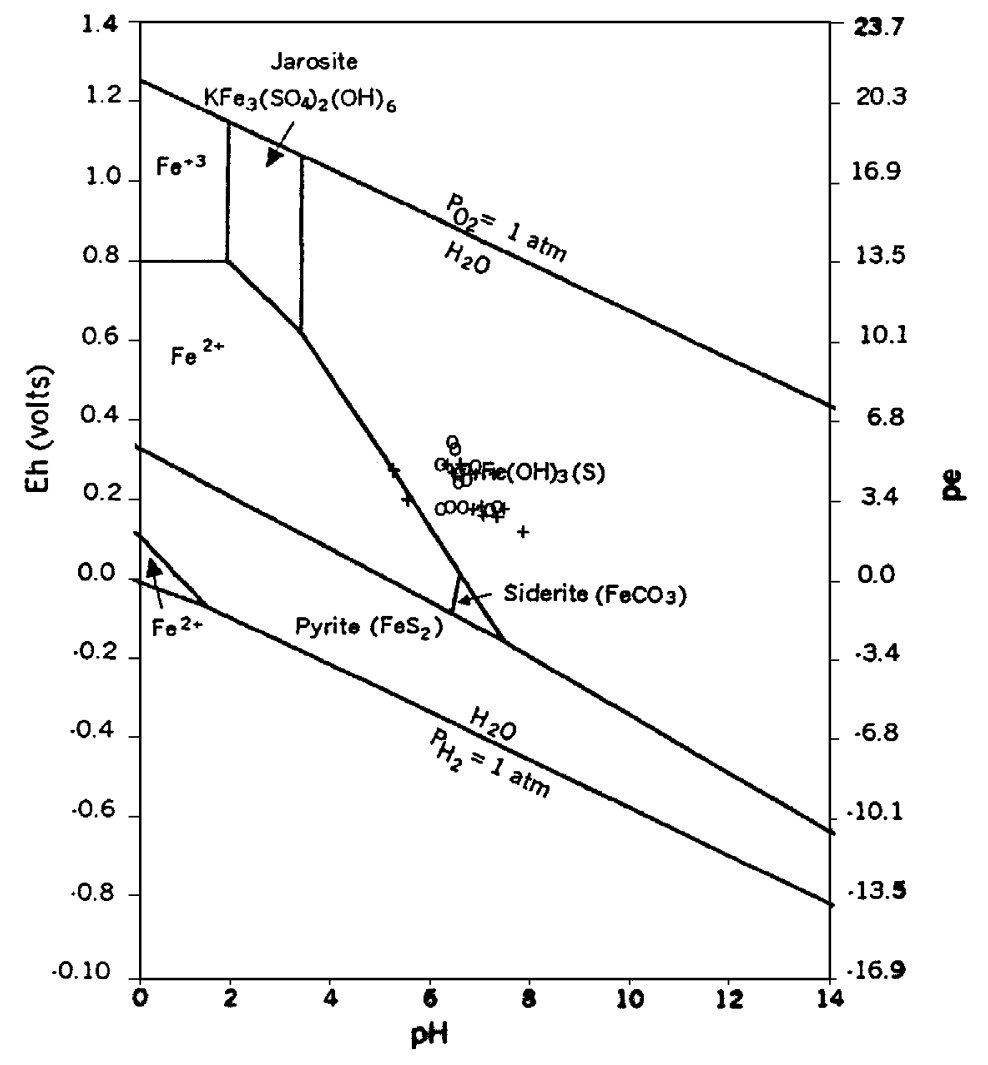

Fig. 7. Plot of water samples from Segura on the Eh-pH diagram for iron species (Deutsch, 1997). Symbols as in Fig. 6.

these veins. Most of the water samples from Segura plot in the $\mathrm{Fe}(\mathrm{OH})_{3}$ field (Fig. 7). Therefore, precipitation of $\mathrm{Fe}(\mathrm{OH})_{3}$ seems to control the $\mathrm{Fe}$ concentration.

The highest $\mathrm{Ba}$ content of $1.6 \mathrm{mg} \mathrm{1^{-1 }}$ (Table 5) was found in water samples 4 and 5, which are close to a quartz vein with barite, galena and sphalerite cutting the schist-metagraywacke complex. Barium content is low because barite has a low solubility at neutral to alkaline $\mathrm{pH}$ conditions (Appelo and Postma, 1993). However, these samples have the lowest $\mathrm{pH}$ (5.20), specific conductance and ionic concentration (Table 5).

$\mathrm{Sn}, \mathrm{B}, \mathrm{Cu}$ and $\mathrm{Pb}$ were not detected in waters from Segura (Antunes, 1999), but they were found in stream sediments and soils (Table 4), which may be explained by their low solubility in water. Their contents in stream sediments and soils probably result mainly by erosion of cassiterite, tourmaline, chalcopyrite and galena (Table 3) from mineralized quartz veins. Anglesite, mimetite and kintoreite were found in $\mathrm{Ba}-\mathrm{Pb}-\mathrm{Zn}$ quartz veins (Table 4) as alteration products of galena, but they are anhydrous.

The $\mathrm{pH}$ of the analyzed waters ranges between 5.20 and 8.25 (Table 5) and, consequently, there is no significant acid drainage associated with the old mine workings at Segura, which is generally responsible for problems of water pollution associated with other mine tailings (Bell, 1998). Commonly, sulphide minerals react with oxygen and water to form sulfuric acid, which reduces the $\mathrm{pH}$ of the system and causes dissolution of metallic compounds and, consequently, large metal concentrations. However, it will not occur if the sulphide minerals are nonreactive or if the rock contains materials to neutralize the acidity and $\mathrm{pH}$ values of water may be near neutral (Bell, 1998). The 
$\mathrm{Sn}-\mathrm{W}$ quartz veins and $\mathrm{Ba}-\mathrm{Pb}-\mathrm{Zn}$ quartz veins from Segura are small and contain some sulphides. These veins mainly intersect the schist-metagraywacke complex containing marble intercalations, which probably neutralized acid waters derived from reaction with sulphide minerals and, consequently, the metal concentration is relatively low as found in others (Rahn et al., 1996).

Generally, the waters from wells and streams have lower concentrations of As, Fe and Mn during winter than during summer, which may be due to dilution effect. However, waters from springs have generally higher concentrations of As, Fe and Mn during winter than during summer, which may be due to the higher volume of infiltrated water, which promotes chemical dissolution of ore minerals. Generally, waters should not be used for human consumption and agriculture due to their As, Fe and Mn concentrations (Table 5).

\section{Conclusions}

(1) At Segura, there are granitic pegmatite veins containing cassiterite and lepidolite, quartz veins with cassiterite and wolframite and quartz veins with barite, galena and sphalerite which fill late- to post-tectonic Hercynian faults, cutting the Cambrian schist-metagraywacke complex and Hercynian granites.

(2) Cassiterite from Li-bearing granitic pegmatite veins from Segura is zoned and darker zones have $\mathrm{Nb}>\mathrm{Ta}$ and $\mathrm{Mn}>\mathrm{Fe}$ and are richer in $\mathrm{Nb}$ and $\mathrm{Ta}$ than lighter zones. The darker zones show exsolutions of manganocolumbite.

(3) Cassiterite from $\mathrm{Sn}-\mathrm{W}$ quartz veins is unzoned, does not show any exsolutions and is richer in $\mathrm{Ti}$ and poorer in $\mathrm{Nb}$ and $\mathrm{Nb}+\mathrm{Ta}$ than cassiterite from Li-bearing granitic pegmatite veins.

(4) Single crystals of wolframite from $\mathrm{Sn}-\mathrm{W}$ quartz veins at Segura have a dominant ferberite component.

(5) At Segura, the $\mathrm{Sn}-\mathrm{W}$ quartz veins contain sulphides (pyrrhotite, arsenopyrite, pyrite, sphalerite, chalcopyrite and stannite) and sulphosalts (matildite and schapbachite), while the sulphides found in the $\mathrm{Ba}-\mathrm{Pb}-\mathrm{Zn}$ quartz veins are cobaltite, pyrite, sphalerite, chalcopyrite and galena. Arsenopyrite is locally altered to scorodite, while anglesite, mimetite and kintoreite are associated with the galena alteration.
(6) Sphalerite from $\mathrm{Ba}-\mathrm{Pb}-\mathrm{Zn}$ quartz veins is richer in $\mathrm{Zn}$ and poorer in $\mathrm{Fe}$ than sphalerite from $\mathrm{Sn}-\mathrm{W}$ quartz veins. Chalcopyrite from $\mathrm{Ba}-\mathrm{Pb}-\mathrm{Zn}$ quartz veins has more $\mathrm{Cu}$ and $\mathrm{Fe}$ than chalcopyrite from $\mathrm{Sn}-\mathrm{W}$ quartz veins.

(7) The $\mathrm{Ba}-\mathrm{Pb}-\mathrm{Zn}$ quartz veins from Segura contain $20-30 \%$ of barite, which has a homogeneous composition and only up to 1.82 wt.\% of SrO.

(8) In parent rocks, $\mathrm{Sn}, \mathrm{W}, \mathrm{Cu}$ and $\mathrm{Zn}$ occur in micas and $\mathrm{Ba}$ and $\mathrm{Pb}$ are retained in $\mathrm{K}$-feldspar and micas. In waste heaps, mine tailings and stream sediments, Sn and W are mainly concentrated in cassiterite and wolframite, respectively, B is retained in tourmaline, As is concentrated in arsenopyrite, $\mathrm{Cu}$ and $\mathrm{Zn}$ are retained in chalcopyrite, $\mathrm{Zn}, \mathrm{Pb}$ and $\mathrm{Ba}$ are concentrated in sphalerite, galena and barite, respectively.

(9) Stream sediments and soils from Segura are generally enriched in metals with respect to parent granite and schist.

(10) The $\mathrm{Sn}, \mathrm{W}, \mathrm{B}, \mathrm{As}$ and $\mathrm{Cu}$ anomalies in stream sediments and soils at Segura are mainly associated with quartz veins containing cassiterite and wolframite and old mining activity on them.

(11) At Segura, the $\mathrm{Ba}, \mathrm{Pb}$ and $\mathrm{Zn}$ anomalies in stream sediments and soils are related to quartz veins with barite, galena and sphalerite and old mining activity on them.

(12) The mechanical process was the most important for $\mathrm{Sn}, \mathrm{W}$ and $\mathrm{B}$ in stream sediments and soils, which are sinks of metals. The abandoned mines increased the mobility of trace elements from mineralized veins to soils, stream sediments and water.

(13) Trace element contents decrease from soils to stream sediments and to water due to their relatively low mobility, particularly shown by the absence of Sn, $\mathrm{B}, \mathrm{Cu}$ and $\mathrm{Pb}$ in waters.

(14) At Segura, there is no significant acid drainage associated with old mine workings, which is mainly attributed to the marble intercalations in the schistmetagraywacke that neutralized the acid waters due to reaction of sulphides with water and oxygen.

(15) Soils must not be used for agriculture and human residences due to the large content in $\mathrm{Sn}, \mathrm{B}$, As and $\mathrm{Ba}$ and $\mathrm{As}$ concentration forbids to use them even for industrial settings.

(16) At Segura, waters associated with $\mathrm{Sn}-\mathrm{W}$ quartz veins and As anomalies in soils are the richest in As, but there is a decrease in As content in waters 
from springs, well and streams with increase in Eh values.

(17) The richest waters in $\mathrm{Fe}$ and $\mathrm{Mn}$ are related to the $\mathrm{Ba}-\mathrm{Pb}-\mathrm{Zn}$ quartz veins. Waters associated with the mineralized veins and old mining activities at Segura have As, Fe and Mn concentrations, which forbid their use for human consumption and agriculture.

\section{Acknowledgements}

We are grateful to Prof. B.J. Wood for the EUGFBristol facility contracts ERBFMGECT 980128 and HPRI-CT-1999-00008 to use the electron microprobe and X-ray fluorescence at the Department of Earth Sciences, University of Bristol, UK and to Prof. M.R. Machado Leite and Dr. J.M. Farinha Ramos for the use of the electron microprobe at Instituto Geológico e Mineiro, S. Mamede de Infesta and to Mineiro IGM for the use of data on stream sediments and soils. The critical reviews by Dr. J. Bruno, Dr. C. Domènech and an anonymous referee are gratefully acknowledged. This research work was carried out in the programme of Geosciences Centre, Coimbra University, Portugal. [EO]

\section{References}

Allen, S.K., Allen, J.M., Lucas, S., 1996. Concentrations of contaminants in surface water samples collected in west-central Indiana impacted by acidic mine drainage. Environ. Geol. 27, 34-37.

Antunes, I.M.H.R. 1999. The impact of abandoned mines on the environment at Segura (central Portugal). MSc thesis. University of Coimbra, Portugal, $162 \mathrm{pp}$.

Appelo, C.A.J., Postma, D., 1993. Geochemistry, Groundwater and Pollution. A.A. Balkema, Rotterdam, pp. 485-502.
Bell, F.G., 1998. Environmental Geology_Principles and Practice. Blackwell Science, Oxford, pp. 415-458.

Boulet, M.P., Larocque, A.C.L., 1998. A comparative mineralogical and geochemical study of sulphide mine tailings at two sites in New Mexico, USA. Environ. Geol. 33, 130-142.

Brooks, R.R., 1972. Geobotany and Biogeochemistry in Mineral Exploration. Harper and Row, New York, 290 pp.

Canadian Council of Ministers of the Environment, 1991. Interim Canadian environmental quality criteria for contaminated sites. CCME EPC-CS34, 1-20, Manitoba.

Deutsch, W.J., 1997. Groundwater Geochemistry, Fundamentals and Applications to Contamination Lewis Publishers, Boca Raton.

Instituto Geológico e Mineiro, 1988. Reports from a prospecting project for tungsten, tin and associated minerals from GóisSegura. Metallic Mineral Prospecting Section. Oporto, Portugal, $10 \mathrm{pp}$.

Marszalek, H., Wasik, M., 2000. Influence of arsenic-bearing gold deposits on water quality in Zloty Stok mining area (SW Poland). Environ. Geol. 39, 888-892.

Neiva, A.M.R., Neiva, J.M.C., Silva, M.M.V.G., 1990. Geochemistry of gold quartz veins walls from Jales (northern Portugal). Chem. Geol. 82, 217-251.

Neiva, A.M.R., Silva, M.M.V.G., Antunes, I.M.H.R., Ramos, J.M.F., 2001. Phosphate minerals of some granitic rocks and associated quartz veins from northern and central Portugal. J. Czech. Geol. Soc. 46, 35-43.

Nickson, R.T., McArthur, J.M., Ravenscroft, P., Burgess, W.G., Ahmed, K.M., 2000. Mechanism of arsenic release to groundwater, Bangladesh and West Bengal. Appl. Geochem. 15, 403-413.

Portuguese law, 1998. Decree No. 236/98 - Portuguese Legislation on Water Quality. I-A, 980-1024, Portugal.

Rahn, P.H., Davis, A.D., Webb, C.J., Nichols, A.D., 1996. Water quality impacts from mining in the Black Hills, South Dakota, USA. Environ. Geol. 27, 38-53.

Rösner, U., 1998. Effects of historical mining activities on surface water and groundwater - an example from northwest Arizona. Environ. Geol. 33, 224-230.

Vink, B.W., 1996. Stability relations of antimony and arsenic compounds in the light of revised and extended $\mathrm{Eh}-\mathrm{pH}$ diagrams. Chem. Geol. 130, 21-30. 